\title{
Circannual inter-relationships among reproductive hormones, gross morphometry, behaviour, ejaculate characteristics and testicular histology in Eld's deer stags (Cervus eldi thamin)
}

\author{
S. L. Monfort ${ }^{1,2}$, J. L. Brown ${ }^{1,2}$, M. Bush ${ }^{1}$, T. C. Wood ${ }^{1}$, \\ C. Wemmer ${ }^{1}$, A. Vargas ${ }^{1}$, L. R. Williamson ${ }^{1}$, R. J. Montali ${ }^{1}$ and \\ D. E. Wildt ${ }^{1,2}$ \\ ${ }^{1}$ National Zoological Park, Departments of Animal Health, Conservation and Pathology, \\ Smithsonian Institution, Front Royal, VA 22630, USA; and 'Department of Biology, \\ Environmental Biology and Public Policy, George Mason University, Fairfax, VA 22039, USA
}

Blood samples, morphometric measurements and behavioural data were collected weekly for 52 weeks from six adult Eld's deer stags exposed to natural fluctuations in photoperiod $\left(38^{\circ} \mathrm{N}\right.$ latitude). Mean $( \pm$ SEM) serum LH concentrations reached peak values in the autumn (October), three months before FSH and testosterone concentrations reached peak values in early winter (January). Prolactin concentrations were inversely related $(r=-0.733$, $P<0.001)$ to $\mathrm{LH}$ and directly related to daylength, and maximal concentrations were observed during mid-summer (July) and minimal concentrations during early winter (January). The temporal pattern of circulating inhibin was positively correlated with FSH $(r=0.88, P<0.001)$, but lagged behind the seasonal FSH increase by $1-3$ weeks. Antler length, body weight and chest girth were maximal during pre-rut (December-January). Maximal scrotal circumference and combined testes volume were observed in mid-winter (February), whereas peak neck girth and behavioural aggression occurred 1-3 months later (March-May). On the basis of quarterly electroejaculation results, motile spermatozoa were produced in all seasons. However, the greatest number of motile spermatozoa per ejaculate was observed during the winter and spring, whereas the highest incidence of sperm pleiomorphisms $(>80 \%)$ was detected in the autumn. Histological assessments of the regressed testis (July) revealed fewer germ cells undergoing spermatogenesis and an increased incidence of degenerating and abnormal cell types. In summary, Eld's deer exhibit a circannual hypothalamic-pituitary-gonadal cycle with onset of pituitary activation occurring during the autumn and winter, whereas gonadal activity peaks during the winter and spring as daylengths are increasing. Marked circannual variations in circulating prolactin suggest that Eld's deer may use photoperiodic cues to modulate seasonal fertility; however, the existence of an endogenous seasonal rhythm operating independently of photoperiod cannot be excluded.

\section{Introduction}

Environmental factors act as proximate cues modulating the onset and cessation of reproductive activity in most seasonally breeding mammals (Lincoln and Short, 1980; Bronson, 1988). Knowledge about seasonal reproduction in male ungulates has been largely derived from studies of domestic rams and temperate deer species. There are 40 cervine species in the family Cervidae, but endocrine control of the annual testicular cycle has been studied only in white-tailed deer (Odocoileus virginianus, McMillin et al., 1974; Mirarchi et al., 1978; Bubenik et al., 1982), black-tailed deer (Odocoileus hemionus columbianus, West and

Received 21 August 1992.
Nordan, 1976), red deer (Cervus elaphus, Lincoln and Kay, 1979; Suttie et al., 1984; Barrell et al,, 1985), wapiti (Cerous elaphus nelsoni, Haigh et al., 1984), roe deer (Capreolus capreolus, Sempéré and Lacroix, 1982; Schams and Barth, 1982), fallow deer (Dama dama, Asher et al., 1989), chital deer (Axis axis, Loudon and Curlewis, 1988), reindeer (Rangifer tarandrus, Whitehead and McEwan, 1973; Mossing and Damber, 1981), caribou (Rangifer arcticus, Stokkan et al., 1980) and rusa deer (Cervus rusas timorensis, van Mourik et al., 1986). With the exception of chital and rusa deer, all of these species exhibit peak fertility during decreasing daylengths.

The Eld's deer (Cervus eldi thamin) is a subtropical species that inhabits monsoonal forests from eastern India to Indochina and southern China $\left(3^{\circ}\right.$ to $25^{\circ} \mathrm{N}$ latitude). Although Eld's deer are not 
exposed to wide seasonal oscillations in photoperiod in their native habitat, they are subjected to an extended rainy season (mid-May to mid-October) (Wemmer and Grodinsky, 1988). Eld's deer hinds are seasonally polyoestrous, spontaneous ovulators: onset of oestrus occurs in late winter or early spring, followed by a 4-6 month seasonal or lactational anoestrus beginning in the autumn (Monfort et al., 1990). The average gestation lasts about 8 months, and $80-90 \%$ of births in captivity occur between September and November in France $\left\langle 48^{\circ} \mathrm{N}\right.$ latitude, Prescott, 1987$)$, the United States $\left(38^{\circ} \mathrm{N}\right.$ latitude, Wemmer and Grodinsky, 1988$)$ and India $\left(25^{\circ} \mathrm{N}\right.$ latitude, Desai and Malhotra, 1970). Stags are fertile at one year of age and exhibit sexual and aggressive behaviours characteristic of 'rut' during late winter and early spring in Southeast Asia (Salter and Sayer, 1986) and the United States (Wemmer and Grodinsky, 1988).

There is a general consensus that deer species living between $20^{\circ} \mathrm{N}$ and $20^{\circ} \mathrm{S}$ exhibit little seasonality in their native habitats and remain aseasonal even when translocated to temperate zones (Lincoln, 1985; Loudon and Brinklow, 1992). However, Eld's deer are unique because they are strongly seasonal in subtropical habitats and do not exhibit a latitudinal shift in the timing or duration of their annual reproductive rhythms, even when translocated to temperate latitudes. Thus, we became interested in studying the similarities and differences in endocrine regulatory mechanisms between this subtropical species and temperate cervids. The present work represents the first in a series of studies detailing the reproductive biology of the male Eld's deer. The objectives here were to characterize and relate circannual rhythms in reproductive hormones to (i) gross morphometry, (ii) behavioural cues indicative of rut, (iii) ejaculate characteristics and (iv) testicular histology.

\section{Materials and Methods}

\section{Animals and sample collections}

Six adult Eld's deer stags (2-8 years of age; $70-120 \mathrm{~kg}$ body weight) were maintained at the Smithsonian Institution's Conservation and Research Center, Front Royal, VA $\left(38^{\circ} \mathrm{N}\right.$ latitude). Deer were housed individually in indoor stalls (3.4 $\mathrm{m} \times 4.6 \mathrm{~m}$ with skylights) connected to outdoor enclosures $(3.6 \mathrm{~m} \times 36.6 \mathrm{~m})$ and exposed to natural fluctuations in photoperiod. Individuals were maintained within visual proximity to other males and within auditory and olfactory proximity to conspecific adult males and females. Blood samples were collected weekly (jugular venepuncture, $10 \mathrm{ml}$ ) from each male after xylazine hydrochloride sedation (Rompun, Mobay Corp., Shawnee, $\mathrm{KA} ; 0.5 \mathrm{mg} \mathrm{kg}^{-1}$, i.m.). After a $2 \mathrm{~h}$ clot time, blood samples were centrifuged $(1500 \mathrm{~g}, 20 \mathrm{~min})$, and sera were harvested and stored at $-70^{\circ} \mathrm{C}$ until analysed.

\section{Luteinizing hormone assay}

Serum LH was analysed using a heterologous ${ }^{125}$ I doubleantibody radioimmunoassay which used a rabbit anti-ovine $\mathrm{LH}$ antiserum (PKC-231A, J. L. Brown) as the first antibody, purified ovine LH (LER-1056-C2, L. E. Reichert, Jr, Albany Medical
College, Albany, NY) as the tracer and ovine LH (NIH-LH-S18, National Pituitary Program, Baltimore, MD) as the standard (Brown et al., 1991a). Serial dilutions of pooled Eld's deer serum yielded displacement curves parallel to that obtained for the $\mathrm{LH}$ standard. The mean recovery of ovine LH (range, 0.03-4 ng per tube) added to Eld's deer serum, after subtraction of endogenous hormone, was $99.3 \pm 3.8 \%\left(y=1.03 x+0.005, r^{2}=0.98\right.$, $P<0.001$ ). Assay sensitivity, calculated as $90 \%$ of maximum binding, was $0.03 \mathrm{ng}$ per tube. The interassay coefficients of variation for two separate internal controls were $10.0 \%$ and $9.9 \%$; intra-assay variation was $<10 \%$.

\section{Follicle-stimulating hormone assay}

Serum FSH was measured using a heterologous ${ }^{125}$ I doubleantibody radioimmunoassay with a rabbit anti-ovine FSH antiserum (JADLER 178, J. A. Dias, Wadsworth Research Institute, Albany, NY), purified ovine FSH (LER-1976-A2, L. E. Reichert, Jr) tracer and ovine FSH (NIH-FSH-S8, National Pituitary Program) standards (Brown et al, 1987). Serial dilutions of serum yielded displacement curves parallel to that obtained with the standard preparation. The mean recovery of ovine FSH (range, 0.78-100 ng per tube), after subtraction of endogenous hormone, was $102.3 \pm 4.4 \%\left(y=1.06 x+0.34, r^{2}=0.99\right.$, $P<0.001$ ). Assay sensitivity was $0.5 \mathrm{ng}$ per tube. The interassay coefficients of variation for two separate internal controls were $11.5 \%$ and $14.4 \%$; intra-assay variation was $<10 \%$.

\section{Inhibin assay}

Concentrations of inhibin in serum were determined in a single assay using an ${ }^{125} \mathrm{I}$ double-antibody radioimmunoassay with an antiserum (JLB 492, J. L. Brown) developed against a synthetic porcine $\alpha(1-30)$ inhibin fragment (inhibin- $\alpha$; N. Ling, Salk Institute, San Diego, CA) (Brown and Chakraborty, 1991). Serial dilutions of serum yielded displacement curves parallel to that obtained with the standard preparation. The mean recovery of inhibin- $\alpha$ (range, $0.0078-0.5 \mathrm{ng}$ per tube), after subtraction of endogenous hormone, was $98.2 \pm 3.5 \%(y=0.98 x+0.06$, $r^{2}=0.99, P<0.001$ ). Assay sensitivity was $0.01 \mathrm{ng}$ per tube, and the intra-assay variation was $<10 \%$.

\section{Prolactin assay}

Serum prolactin was measured using a ${ }^{125} I$ double-antibody radioimmunoassay with an anti-human prolactin antisera (NIDDK-human prolactin-3, National Pituitary Program) and ovine prolactin (NIDDK-ovine prolactin-I-2, National Pituitary Program) as the tracer and standard (Brown et al., 1992). Serial dilutions of serum yielded displacement curves parallel to that obtained with the standard preparation. The mean recovery of ovine prolactin (range, $0.019-2.5 \mathrm{ng}$ per tube), after subtraction of endogenous hormone, was $97.3 \pm 4.1 \%(y=0.92 x+0.017$, $r^{2}=0.99, P<0.001$ ). Assay sensitivity was $0.02 \mathrm{ng}$ per tube, and the inter-and intra-assay coefficients of variation were $7.5 \%$ and $9.2 \%$, respectively.

\section{Testosterone assay}

Serum testosterone was analysed in unextracted serum using an ${ }^{125}$ I radioimmunoassay kit (ICN, Costa Mesa, CA). Serial 
dilutions of serum yielded displacement curves parallel to that obtained with the standard preparation. The mean recovery of testosterone (range, $0.1-10 \mathrm{ng} \mathrm{ml}^{-1}$ ) was $99.4 \pm 3.1 \%$ $\left(y=1.01 x-0.002, r^{2}=0.99, P<0.001\right)$. Assay sensitivity was $0.1 \mathrm{ng} \mathrm{ml}^{-1}$; the interassay coefficient of variation was $12.9 \%$, and intra-assay variation was $<10 \%$.

\section{Gross morphometry}

Before weekly blood sampling, each male was weighed using an electronic platform scale. Anaesthesia (xylazine, 0.3$0.5 \mathrm{mg} \mathrm{kg}^{-1}$ i.m.) then was induced, and antler length, neck and chest girth were measured by the same individual on the research team. Antler growth was measured by determining curved brow-tine and main beam lengths from when antlers were cast (June-July). These data were reported as the combined length $(\mathrm{cm})$ of both right and left antlers. Stage of antler development (velvet, hard antler or casting) and the dates of natural velvet stripping were recorded. A flexible tape was used to measure neck (circumference at the base of the neck, cranial to the scapulae) and chest (circumference about $10 \mathrm{~cm}$ cranial to the last rib) girths while each animal was positioned in right lateral recumbency. Vernier calipers were used to determine the length and width of each testis, and these values were converted to combined testes volume per animal (Wildt et al., 1982). Scrotal circumference was measured with a flexible tape while both testes were positioned in the distal portion of the scrotum (Chenoweth and Ball, 1980).

\section{Behavioural aggression}

A subjective aggression score was recorded weekly for each male. All observations were made by a single individual with scoring based on the ability of this investigator to shift each stag from the animal's stall to a weighing platform using voice commands. The grading scale ranged from one (a timid animal that readily moved away and onto the platform in response to voice commands) to five (an animal that responded aggressively by ignoring the command and approaching the handler in a threatening 'head down' attack posture).

\section{Electroejaculation and semen evaluation}

Semen was collected from each male within 2 weeks of the summer solstice (June 21), autumn equinox (September 22), winter solstice (December 21) and spring equinox (March 20). Each animal was anaesthetized using a combination of ketamine (Ketaset, Aveco Co., Fort Dodge, IA; about $2 \mathrm{mg} \mathrm{kg}^{-1}$ ) and xylazine (about $0.25 \mathrm{mg} \mathrm{kg}^{-1}$ ) administered i.m., and semen was collected using a standardized electroejaculation protocol (Howard et al., 1986). A sine-wave electrostimulator (AC $60-\mathrm{Hz}$ ) and rectal probe (P.T. Electronics, Boring, OR) were used to administer 90 incremental stimuli given in a $3 \mathrm{~s}$ on-off pattern in three series consisting of 30 (10 stimulations at 4,5 and $6 \mathrm{~V}$, respectively), 30 (10 stimulations at 5,6 and $7 \mathrm{~V}$ ) and 30 (10 stimulations at 6,7 and $8 \mathrm{~V}$ ) stimuli. Each series was separated by a 5 min rest interval at which time aliquots of semen were assessed for volume and concentration of spermatozoa. At least four separate fields ( $\times 250$ ) were examined, and an average sperm motility and status rating were calculated. Sperm status was a subjective assessment of forward progressive motility on a graded scale: 0 , no movement to 5 , rapid, steady forward progression (Howard et al., 1986). After combining and mixing semen from all three series, a $20 \mu \mathrm{l}$ seminal aliquot was fixed in $1 \%$ glutaraldehyde, and the structural integrity of 200 sperm cells was assessed under oil by phase-contrast $(x 1200)$ microscopy (Howard et al., 1986). Spermatozoa were classified as normal or having an abnormal acrosome, tightly coiled flagellum, no midpiece, bent midpiece with or without cytoplasmic droplet, bent flagellum, proximal or distal cytoplasmic droplet or head detached from the midpiece-flagellum.

\section{Testicular biopsy}

Seasonal differences in spermatogenesis at the gonadal level were confirmed by obtaining a single testicular biopsy from each of nine different stags during the peak (February, $n=3$ ) and nadir (July, $n=6$ ) of testicular activity as judged by scrotal circumference. The three stags from which biopsies were taken during February were age-matched males not included in the circannual study, whereas biopsies were taken from all six study deer once during July. After surgical preparation of the scrotum, a $2 \mathrm{~cm}$ antescrotal, midline skin incision was made and the tunica vaginalis penetrated until parenchyma was exposed. A wedge of tissue (about $300 \mathrm{mg}$ ) was excised with a scalpel and immersed in Trump-McDowell fixative (McDowell, 1978). Each specimen was imbedded in paraffin, sectioned with a tissue microtome $(5 \mu \mathrm{m})$, stained with haematoxylin and eosin, and then examined by light microscopy $(\times 10-400)$ to determine the relative stages of germ cell development.

\section{Statistical analyses}

Morphometric measurements, hormonal concentrations and ejaculate characteristics are presented as means \pm SEM. All statistical comparisons were performed using Statview $512^{+}$ (BrainPower, Inc., Calabasas, CA) on a Macintosh computer. Comparisons among weekly and seasonal parameters were determined using correlation analyses and repeated measures analysis of variance. Multiple comparisons were made using Fisher's protected least significant difference test.

\section{Results}

\section{Seasonal changes in circulating hormone concentrations}

Between mid-summer and mid-autumn (Fig. 1a), testosterone concentrations (Fig. Ib) were low (July-October; mean range $\left.0.07-0.43 \mathrm{ng} \mathrm{ml}^{-1}\right)$ and increased $(P<0.05)$ about sixfold above baseline values as winter approached (mid-November and December; mean range $0.44-1.86 \mathrm{ng} \mathrm{ml}^{-1}$ ). Peak testosterone concentrations were observed in winter, 3 months after the $\mathrm{LH}$ peak (January to mid-March; mean range $2.71-7.41 \mathrm{ng} \mathrm{ml}^{-1}$ ). Thereafter, testosterone declined steadily to basal concentrations $\left(<0.50 \mathrm{ng} \mathrm{ml}^{-1}\right)$ by early July. 
Mean weekly serum LH concentrations (Fig. Ic) were lowest during early summer (July; mean range $0.88-0.94 \mathrm{ng} \mathrm{ml}^{-1}$ ), reached peak values as daylengths were declining during late autumn (October, $2.47 \pm 0.37 \mathrm{ng} \mathrm{ml}^{-1}$ ) and then gradually decreased during the next 6 months to about $1.0 \mathrm{ng} \mathrm{m}^{-1}$ by late spring (May-June; mean range $0.97-1.19 \mathrm{ng} \mathrm{ml}^{-1}$ ).

Prolactin concentrations (Fig. 1c) were uniformly low throughout the autumn and winter (October-March; mean range $1.1-6.5 \mathrm{ng} \mathrm{ml}^{-1}$ ). Concentrations were above baseline values by mid-spring (April; $P<0.05,17.4 \pm 5.3 \mathrm{ng} \mathrm{ml}^{-1}$ ), increasing gradually throughout the late spring and summer to reach peak concentrations in early August (102.0 \pm $35.8 \mathrm{ng} \mathrm{ml}^{-1}$ ). Prolactin then declined sharply by early autumn (October; mean, $2.2 \pm 1.2 \mathrm{ng} \mathrm{ml}^{-1}$ ), just 2 weeks before the marked $\mathrm{LH}$ rise. Circannual $\mathrm{LH}$ and prolactin concentrations were inversely related $(r=-0.73, P<0.001)$.

Serum FSH concentrations (Fig. 1d) were lowest during the summer (July; mean $14.9 \pm 3.4 \mathrm{ng} \mathrm{ml}^{-1}$ ), but increased $(P<0.05)$ from mid-autumn (late October; mean $64.8 \pm$ $8.8 \mathrm{ng} \mathrm{m}^{-1}$ ), and continued to a peak value in January ( $120.7 \pm 20.6 \mathrm{ng} \mathrm{ml}^{-1}$ ). During the next 4 months, FSH declined gradually to nadir concentrations by May-June (mean range, 18.4-28.2 $\mathrm{ng} \mathrm{ml}^{-1}$ ).

The temporal mean inhibin profile(Fig. 1d) mirrored that of FSH for both the upstroke $(r=0.95)$ and downstroke $(r=0.96$; both $P<0.001$ ) of the seasonal cycle. However, the overall correlation for the entire unlagged cycle $(r=0.88)$ improved when FSH data were lagged behind inhibin for 1 week $(r=0.90), 2$ weeks $(r=0.92)$ or 3 weeks $(r<0.93)(P<0.001)$. Weekly mean inhibin was consistently low from late spring to the end of summer (May-September; mean range $0.43-0.52 \mathrm{ng} \mathrm{m}^{-1}$ ), reaching a peak $(P<0.05)$ in January (mean range, $0.74-0.84)$ and then steadily declining to baseline values by the last week in April (mean $0.59 \pm 0.04 \mathrm{ng} \mathrm{ml}^{-1}$ ).

\section{Seasonal changes in gross morphometry and behaviour}

All antlers remaining from the previous year were cast by mid-summer and new velvet antler growth (Fig. 2a) occurred from late summer to early winter. All males had stripped antler velvet by January. Mean body weight (Fig. 2b) increased steadily (about $0.9 \mathrm{~kg}$ per week) from a nadir of $87.8 \pm 5.2 \mathrm{~kg}$ in mid-summer (early July) to a pre-rut maximum of $105.0 \pm 5.5 \mathrm{~kg}$ by mid-winter (late January); weight declined thereafter until July. Mean neck girths (mean range $56.8-60.8 \mathrm{~cm}$; Fig. 2c) were lowest throughout summer (July-September), but gradually increased to peak values in February (mean range $70.6-74.7 \mathrm{~cm}$ ). Mean chest girths (Fig. 2d) were lowest during summer (July-August; mean range $106.9-115.8 \mathrm{~cm}$ ). In slight contrast to neck measurements, maximum chest girths (mean range $119.3-124.8 \mathrm{~cm}$ ) were observed during early- to midwinter (late November-February). Mean body weight, neck and chest girths did not return to values measured at the onset of the study, presumably because these deer generally continued growth and development.

Behavioural aggression scores were lowest throughout the summer (July-September), but increased steadily thereafter until all males displayed peak and sustained aggressive behaviour in spring (March-May) (Fig. 3a). Maximum aggressiveness was not
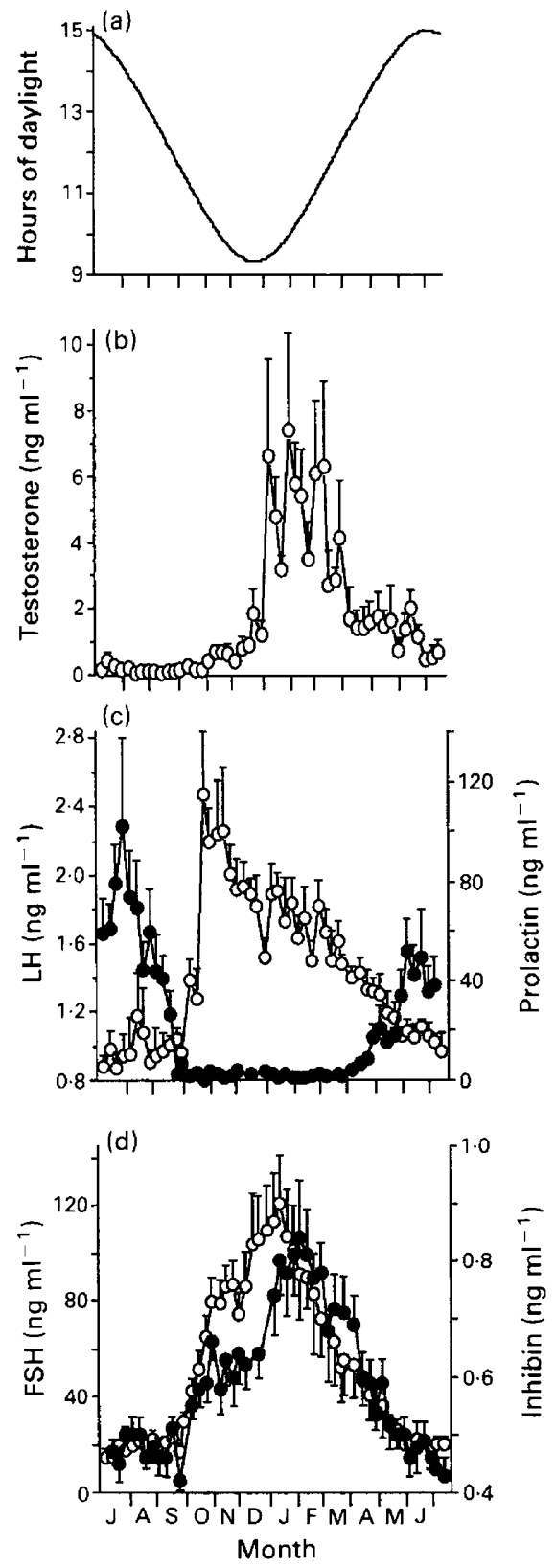

Fig. 1. (a) Hours of daylight at the study site $\left(38^{\circ} \mathrm{N}\right.$ latitude) are shown. Weekly mean ( \pm SEM) serum (b) testosterone, (c, O) LH, (c, O) prolactin, (d, O) FSH and (d, O) inhibin from six Eld's deer stags sampled from July 1989 to June 1990.

detected until after serum testosterone and testicular size began to decline, but spermatozoa concentration and quality remained high during this time. The level of aggression declined sharply during May and June in all males. Scrotal circumference and combined testes volume (Fig. 3 b) profiles were temporally similar. Both measures increased steadily (scrotal circumference, $0.3 \mathrm{~cm}$ per week; testes volume, $27.5 \mathrm{~cm}^{3}$ per week) from a nadir during mid-September (circumference $14.9 \pm 0.7 \mathrm{~cm}$; volume $202.1 \pm$ $15.0 \mathrm{~cm}^{3}$ ) to a peak during early February (circumference $20 \cdot 7 \pm 1 \cdot 1 \mathrm{~cm}$; volume $752 \cdot 0 \pm 51 \cdot 3 \mathrm{~cm}^{3}$ ). Mean testicular volume during the nadir of the testicular cycle (August- 

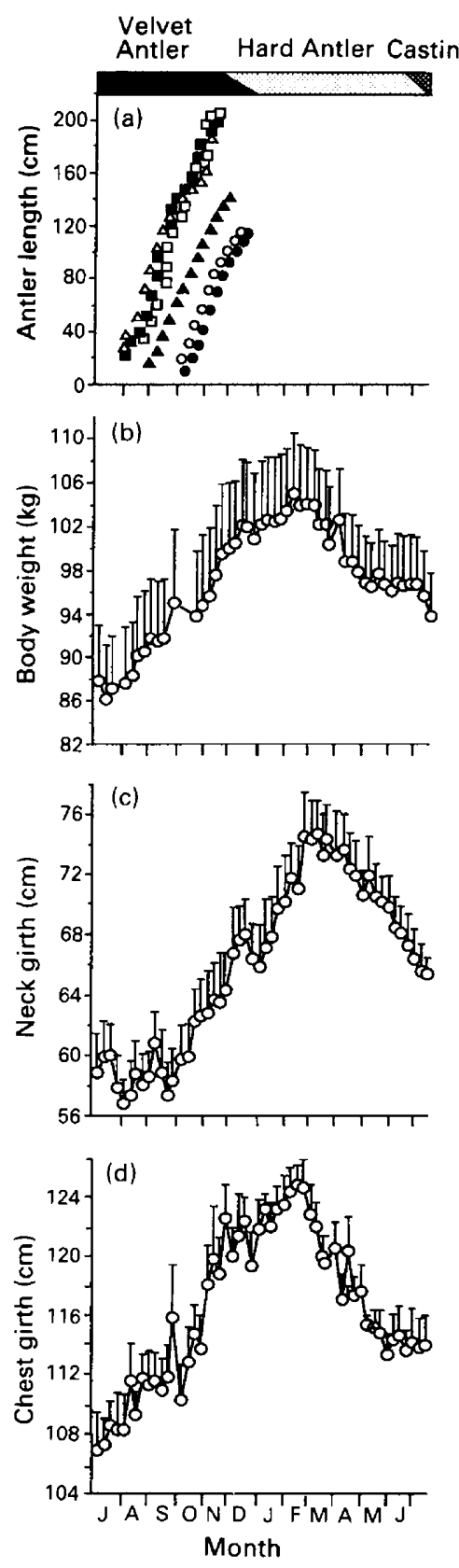

Fig. 2. (a) Stages of antler development (velvet and hard antler) and the approximate time that antlers were shed are shown. Weekly mean ( $\pm \mathrm{SEM}$ ) (a) antler length, (b) body weight, (c) neck girth and (d) chest girth for six Eld's deer stags throughout 1 year.

September) was $24.6 \pm 1.9 \%$ (range 19.1 to $33.1 \%$ ) of the seasonal maximum (December to February).

\section{Seasonal changes in ejaculate characteristics and testicular histology}

Ejaculate volume (Table 1$)$ was lowest $(P<0.05)$ during the spring than during all other seasons and highest during the winter. Motile spermatozoa were detected in the ejaculates of all males in all seasons of the year. The percentage sperm
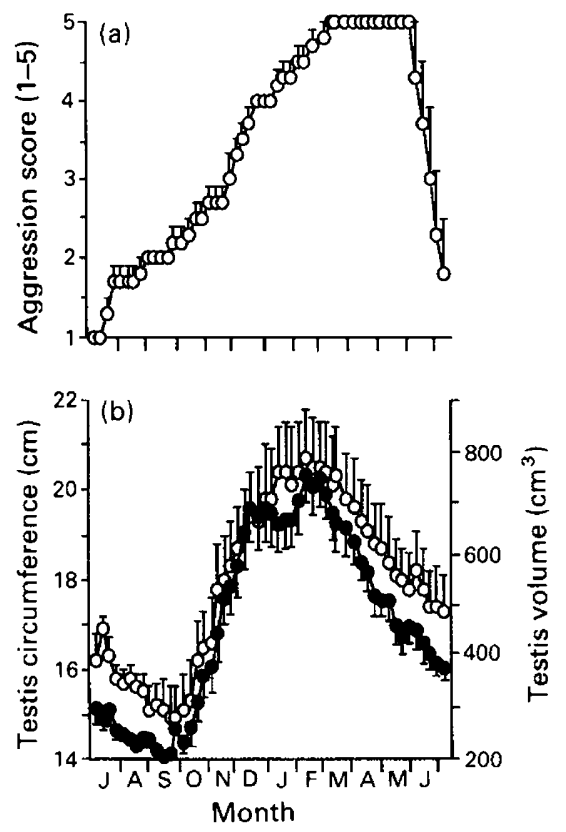

Fig. 3. Weekly mean ( \pm SEM) values of (a) behavioural aggression score, $(b, O)$ scrotal circumference and $(b, O)$ combined testes volume for six Eld's deer stags.

motility during the autumn was lower than during the winter $(P<0.05)$. However, sperm motility ratings were similar $(P>0.05)$ during the winter, spring and summer. Progressive sperm status was lower during the summer than during the winter $(P<0.05)$; however, there were no differences $(P>0.05)$ in status assessments among the winter, spring and autumn. Although the total number of motile spermatozoa per ejaculate was greater $(P<0.05)$ during the winter than during the autumn, the numbers of motile spermatozoa per ejaculate during the winter $(P>0.05)$ were similar to values observed during the spring and summer.

The percentage of structurally normal spermatozoa per ejaculate was more than four times higher $(P<0.05)$ in the winter and spring $(85.7 \%$ and $91.6 \%$, respectively) than in the autumn $(18.2 \%)$. During the autumn, the most common morphological defect was spermatozoa with abnormal acrosomes $(>30 \%$ ), although $>25 \%$ of the pleiomorphisms consisted of residual protoplasmic droplets: $>10 \%$ had detached heads. Abnormal acrosomes $(>17 \%)$ were also commonly observed during the summer with the majority of the remaining abnormalities consisting of residual, distal cytoplasmic droplets. During winter and spring, spermatozoa with abnormal acrosomes were absent from all ejaculates, and the few pleiomorphisms observed consisted mostly of immature spermatozoa with cytoplasmic droplets.

Histological evaluations of the testicular biopsies collected in February revealed active spermiogenesis with many rounded and elongated spermatids and spermatozoa near or within the enlarged tubular lumens (Fig. 4a). Germ cell populations were distributed uniformly throughout the tubule. Few multinucleated giant spermatids were observed, and Leydig cells were prominent. In contrast, testicular biopsies collected during July revealed decreased numbers of spermatogonia and spermatids 
Table 1. Characteristics of semen ejaculates in six Eld's deer stags collected during four seasons of the year

\begin{tabular}{|c|c|c|c|c|}
\hline Ejaculate traits & $\begin{array}{l}\text { Summer } \\
\text { solstice }\end{array}$ & $\begin{array}{l}\text { Autumn } \\
\text { equinox }\end{array}$ & $\begin{array}{l}\text { Winter } \\
\text { solstice }\end{array}$ & $\begin{array}{l}\text { Spring } \\
\text { equinox }\end{array}$ \\
\hline Ejaculate volume (ml) & $2.95 \pm 0.42^{\mathrm{ab}}$ & $2.11 \pm 0.61^{a}$ & $3.49 \pm 0.36^{\mathrm{b}}$ & $0.69 \pm 0.03^{\mathrm{c}}$ \\
\hline Sperm motility $(\%)$ & $55 \pm 14^{\mathrm{ab}}$ & $43 \pm 14^{\mathrm{a}}$ & $80 \pm 2^{b}$ & $71 \pm 6^{\mathrm{ab}}$ \\
\hline Motile spermatozoa per ejaculate $\left(\times 10^{6}\right)$ & $760 \pm 246^{\mathrm{ab}}$ & $213 \pm 131^{\mathrm{a}}$ & $1603 \pm 370^{\mathrm{b}}$ & $800 \pm 302^{\mathrm{ab}}$ \\
\hline Progressive status $(0-5$ scale $) \dagger$ & $2.3 \pm 0.7^{\mathrm{a}}$ & $3.2 \pm 0.7^{\mathrm{ab}}$ & $4.0 \pm 0.0^{\mathrm{b}}$ & $3.6 \pm 0.1^{\mathrm{ab}}$ \\
\hline Structurally normal spermatozoa (\%) & $61.3 \pm 15.8^{\mathrm{a}}$ & $18.2 \pm 5.9^{\mathrm{b}}$ & $85.7 \pm 5.4^{c}$ & $91.6 \pm 1.1^{c}$ \\
\hline \multicolumn{5}{|l|}{ Structurally abnormal spermatozoa (\%) } \\
\hline Abnormal acrosome & $17.2 \pm 13.3^{\mathrm{ab}}$ & $32.2 \pm 13.6^{b}$ & $0.0 \pm 0.0^{\mathrm{a}}$ & $0.0 \pm 0.0^{\mathrm{a}}$ \\
\hline Tightly coiled flagellum & $3.8 \pm 2.1$ & $4.0 \pm 1.9$ & $0.2 \pm 0.1$ & $0.3 \pm 0.2$ \\
\hline No midpiece & $0.1 \pm 0.1$ & $0.3 \pm 0.2$ & $0.0 \pm 0.0$ & $0.0 \pm 0.0$ \\
\hline Bent midpiece with cytoplasmic droplet & $1.8 \pm 0.9^{\mathrm{a}}$ & $6.5 \pm 2.4^{\mathrm{b}}$ & $2.1 \pm 1.0^{\mathrm{ab}}$ & $0.5 \pm 0.3^{\mathrm{a}}$ \\
\hline Bent midpiece without cytoplasmic & & & & \\
\hline droplet & $0.9 \pm 0.2^{\mathrm{ab}}$ & $1.8 \pm 0.6^{\mathrm{a}}$ & $0.1 \pm 0.1^{b}$ & $0.3 \pm 0.2^{b}$ \\
\hline Bent flagellum & $1.0 \pm 0.5^{\mathrm{a}}$ & $0.1 \pm 0.1^{\mathrm{b}}$ & $0.0 \pm 0.0^{b}$ & $0.0 \pm 0.0^{b}$ \\
\hline Proximal droplet & $1.6 \pm 0.9^{\mathrm{a}}$ & $25.8 \pm 7.3^{b}$ & $6.2 \pm 2.2^{\mathrm{a}}$ & $4.8 \pm 0.8^{\mathrm{a}}$ \\
\hline Distal droplet & $11.5 \pm 7.5$ & $1.2 \pm 0.5$ & $5.8 \pm 2.4$ & $2.5 \pm 0.4$ \\
\hline Detached head & $0.8 \pm 0.8^{\mathrm{a}}$ & $10.1 \pm 5.0^{b}$ & $0.0 \pm 0.0^{\mathrm{a}}$ & $0.0 \pm 0.0^{\mathrm{a}}$ \\
\hline
\end{tabular}

${ }^{*}$ Values are means $\pm \mathrm{SEM}$, and within row means with different superscripts are significantly different $(P<0.05)$.

†Sperm status was a subjective assessment of forward progressive motility on a graded scale: 0 , no movement to 5 , rapid, steady forward progression.

within the seminiferous tubules (Fig. 4b). Degenerating spermatids, cellular remnants, multinucleated giant cells and a heterogeneous population of spermatids and spermatocytes dominated the tubular lumina. In addition, germ cell populations were distributed irregularly within the tubular epithelium and Leydig cells were not prominent.

\section{Discussion}

Eld's deer represent a striking example of a subtropical species that exhibits similar seasonal reproductive patterns in their native habitat, even in several generations after translocation to northern temperate latitudes. Unlike most temperate, 'shortday' breeding cervids, maximum testicular growth, antler development and behavioural aggression occurred in Eld's deer during the winter and spring, as daylength increased. Antler formation corresponded to cyclic fluctuations in LH, FSH and testosterone in a similar way to that described for other cervids (Suttie et al., 1984). However, the hormonal rhythms were shifted 6 months out-of-phase relative to most temperate deer. Antler growth began before LH and FSH increased and continued while LH and FSH concentrations were high and testosterone and prolactin were low. Like all other cervid species studied, antler mineralization and velvet stripping occurred when concentrations of testosterone were high, whereas casting occurred after testosterone was low (Suttie et al., 1984).

Despite the seasonal phase difference between Eld's deer and other temperate cervids, the interactive dynamics of the pituitarygonadal axis were similar. LH concentrations reached peak values 3 months before maximum FSH and testosterone concentrations; this pattern is similar to the testicular reactivation pattern of red deer (Lincoln and Kay, 1979). Because testosterone reached peak values as LH declined, increased testosterone secretion may have been associated with enhanced testicular sensitivity to $\mathrm{LH}$ rather than to increased pituitary $\mathrm{LH}$ secretion. Similar changes in testicular sensitivity have been related to altered numbers of testicular LH receptors in rams (Sanford et al., 1984) and impala (Brown et al., 1991b). Overall, our data were similar to observations of white-tailed deer (Bubenik et al., 1982), roe deer (Sempéré and Lacroix, 1982) and red deer (Suttie et al., 1984), supporting the concept that LH is critical for initiating testicular steroidogenic activity, whereas FSH and testosterone are important for supporting spermatogenesis later, during the peak of the circannual testicular cycle.

Eld's deer were also similar to white-tailed deer (Mirarchi et al., 1978; Bubenik et al., 1982) in that seasonal peak FSH concentrations occurred later than peak LH and closely paralleled the testosterone cycle and sperm production. In addition to playing a primary role in controlling spermatogenesis, $\mathrm{FSH}$ also stimulates inhibin secretion, presumably from the Sertoli cells (de Jong, 1988). To our knowledge, this is the first report describing inhibin immunoreactivity in any cervid. The close temporal correspondence between circulating profiles of FSH and inhibin suggest that FSH was modulating inhibin secretion in Eld's deer. Similar temporal relationships have been reported in rams (Lincoln and McNeilly, 1989; Lincoln et al., 1990), supporting the concept of a dynamic feedback relationship between these two hormones. Our data suggest that FSH supported seminiferous tubular development during seasonal testicular reactivation and presumably stimulated increased inhibin secretion from Sertoli cells. Although FSH and inhibin patterns were correlated during both the upstroke and downstroke of the circannual cycle, inhibin concentrations continued to rise for 3 weeks after FSH began to decline in January during peak testicular activity. This result suggests that there is a dynamic change in hormonal interrelationships, because inhibin secretion appeared to 'catch up' with FSH secretion, eventually achieving sufficiently high concentrations to dampen further FSH release effectively. 

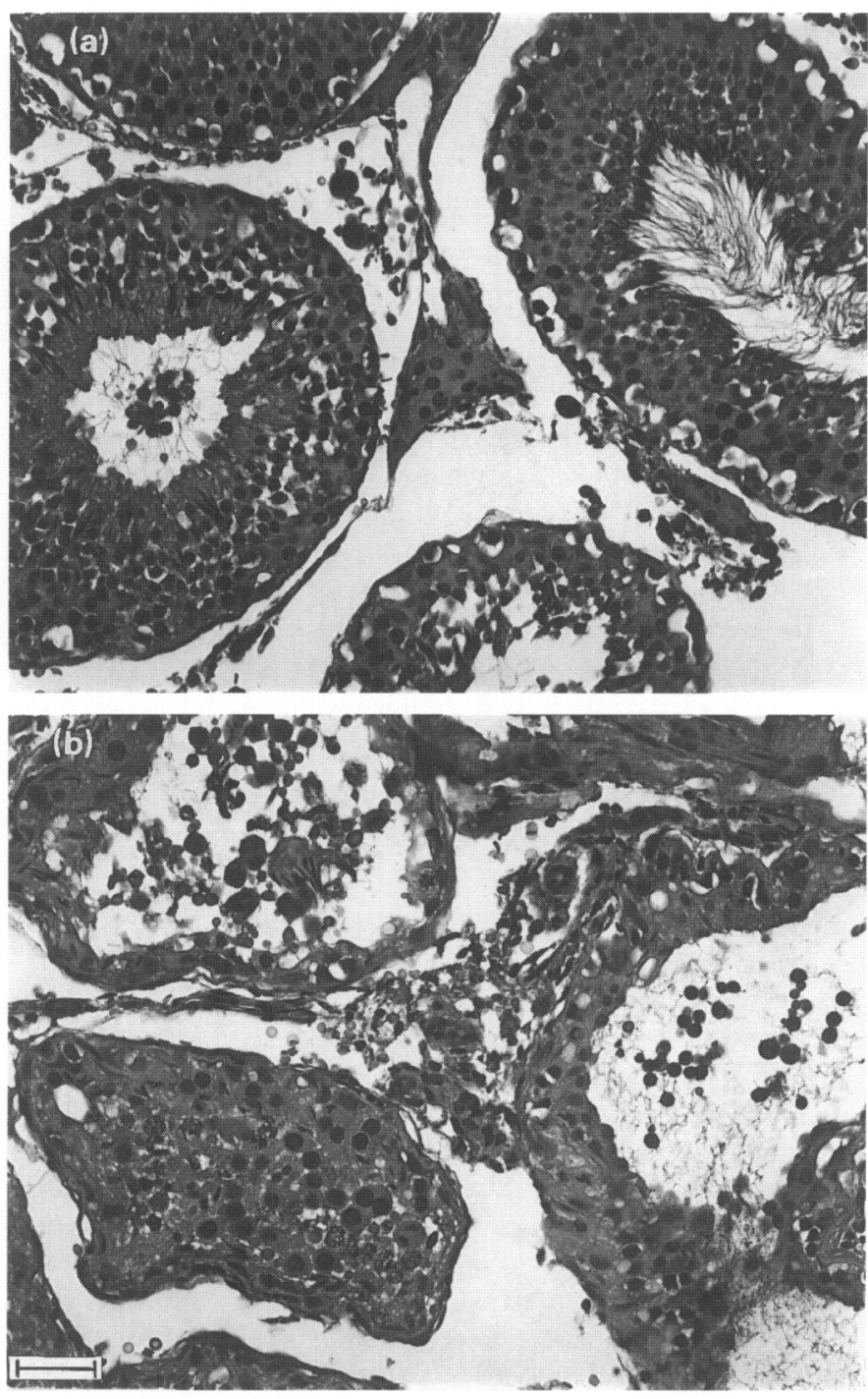

Fig. 4. Seminiferous tubules from the testis of adult Eld's deer stags (a) biopsied at the peak (February) and (b) nadir (July) of the testicular cycle. (a) Active spermiogenesis with an evenly distributed population of germ cells and prominent Leydig cells can be seen. (b) A heterogeneous population depleted of seminiferous tubules with luminal populations of degenerating spermatids, cellular remnants and multinucleated giant cells indicative of the regressed testis can be seen. Scale bar $=33 \mu \mathrm{m}$.

Prolactin secretory patterns in Eld's deer were directly related to daylength and maximum concentrations were observed during long days and minimal concentrations during short days. Red deer (Kelly et al., 1982), white-tailed deer (Mirarchi et al., 1978; Shulte et al., 1981; Bubenik et al., 1990), reindeer (Ryg and Jacobson, 1982), roe deer (Schams and Barth, 1982) and rusa deer (van Mourik and Stelmasiak, 1985) exhibit similar temporal patterns with maximum prolactin secretion occurring about the time of the summer solstice, regardless of latitude (Fig. 5). In contrast, peak concentrations of prolactin in Père David's deer (Elaphurus davidianus) occur about 6 weeks before the summer solstice, and it has been suggested that this shift is related to an

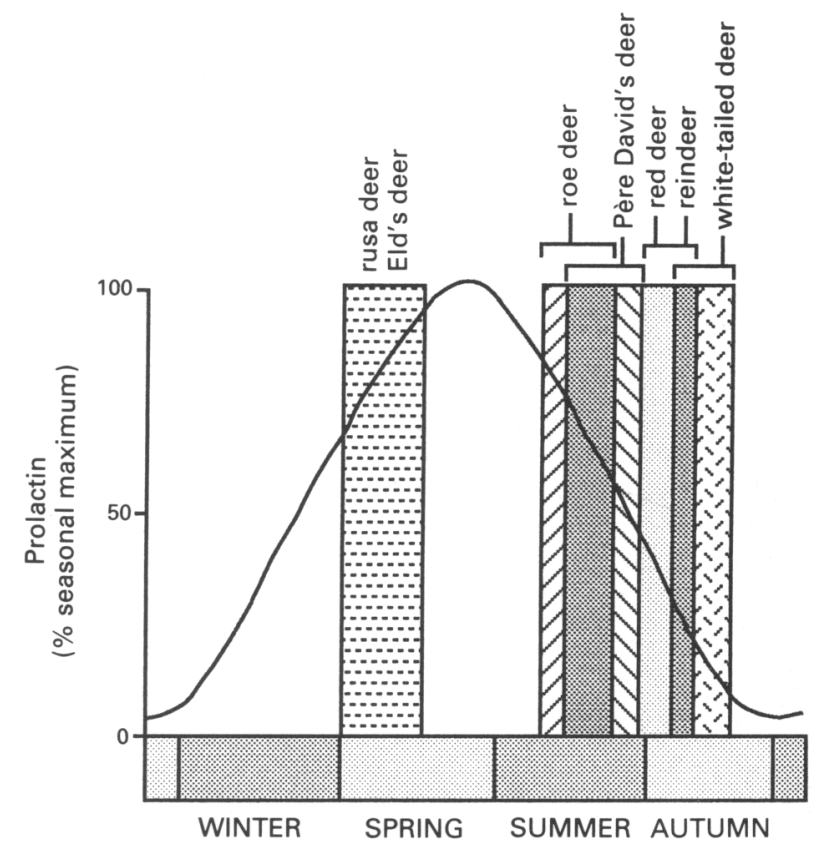

Fig. 5. Schematic representation of the relationship between the timing of nut and the circannual secretory rhythm of prolactin in various cervids. Data were adapted from the following citations: Kelly et al., 1982 (red deer); Mirarchi et al., 1978; Shulte et al., 1981; Bubenik et al., 1990 (white-tailed deer); Ryg and Jacobson, 1982 (reindeer); Schams and Barth, 1982 (roe deer); van Mourik and Stelmasiak, 1985 (rusa deer); and Loudon et al., 1989 (Père David's deer).

early calving season relative to temperate deer species (Loudon et al., 1989; Loudon, 1991).

The significance of prolactin as a modulator of the reproductive axis remains controversial. A striking inverse relationship was observed in Eld's deer between temporal patterns of prolactin and LH secretion. In white-tailed deer, Bubenik et al. (1990) suggested that prolactin modulates the sensitivity of the testes to LH via receptor-mediated mechanisms and acts as a secondary messenger of photoperiodically dependent seasonality. It is possible that prolactin may play a similar role in regulating the Eld's deer reproductive axis. However, it is also possible that the prolactin secretory rhythm simply reflects changing photoperiod and is unimportant in regulating seasonal reproduction. Evaluation of a growing database for cervids reveals that rutting activity can occur during either the upstroke or downstroke of the circannual prolactin rhythm. This result appears to refute assertions that prolactin acts to stimulate or inhibit reproduction in 'long-day' (roe deer, Schams et al., 1987) or 'short-day' (Bubenik et al., 1987) breeding deer, and reveals the misleading implications of 'long-day' and 'short-day' terminologies. For example, although peak testicular activity in Eld's deer is achieved as daylengths are increasing, their testicular cycle is phase-shifted almost 6 months earlier compared with roe deer, another 'long-day' breeder. Whereas prolactin increases in parallel with LH in roe deer (Schams et al., 1987), our study here demonstrated that these hormones were inversely related in Eld's deer. Thus, characterizing prolactin as simply pro- or anti-gonadotrophic in relation to long- or short-day breeding 
rhythms in cervids (Bubenik, 1990) appears to be a great oversimplification, and further studies are warranted to understand this interrelationship clearly.

There was a close temporal relationship between the seasonal cycle of prolactin secretion and growth of the pelage in Eld's deer stags. Stags develop a greyish-brown coat during the winter, and moult occurs during late spring (as prolactin is increasing) resulting in a reddish-brown summer coat. Thus, the relationship between prolactin and pelage growth in Eld's deer is consistent with a role for prolactin in controlling the annual cycle of moult and growth of the pelage that has been demonstrated in other ungulates (Lincoln, 1990).

A seasonal cycle in body weight, neck and chest girths was also observed in Eld's deer that was qualitatively similar to that observed in red deer (Suttie et al., 1984), chital (Loudon and Curlewis, 1988) and fallow deer (Asher et al., 1989). This seasonal pattern presumably reflects endogenous metabolic processes that are independent of gonadal steroid secretion and ad libitum food intake (see review, Loudon and Brinklow, 1992). Eld's deer stags, as found for all cervids, exhibit a notable increase in voluntary food intake during the pre-rut period that presumably serves to maximize their body condition for rut.

The finding reported here that behavioural aggressiveness of Eld's deer was greatest as testosterone concentration and testis size were declining was similar to earlier reports in red deer stags (Lincoln and Guinness, 1973) and Soay rams (Lincoln and Davidson, 1977). Aggressive behaviours in ungulates generally coincide with changes in sexual libido and mating behaviour in ungulates (Fraser, 1968). The results reported here are consistent with a primary role for gonadal steroids in inducing sexual and aggressive behaviours indicative of rut in Eld's deer stags.

The general decline in the number of germ cells undergoing active spermatogenesis and the increased number of immature and abnormal cells in the regressed Eld's deer testis (July) were similar to histological evaluations of roe deer (Short and Mann, 1966), red deer (Lincoln, 1971), fallow deer (Chaplin and White, 1972), black-tailed deer (West and Nordan, 1976), white-tailed deer (Wislocki, 1943), reindeer (Meschaks and Nordkvist, 1962) and chital (Loudon and Curlewis, 1988). Although producing ejaculates containing spermatozoa during all seasons, Eld's deer exhibited a high incidence of sperm pleiomorphisms per ejaculate, particularly acrosomal defects during the regressed nadir of the testicular cycle. Sperm pleiomorphisms, including deformed acrosomes and flagella, occur commonly in a variety of seasonally breeding mammals during testicular regression (for review, see Lincoln, 1981). Although the aetiology of sperm defects is unknown, degenerative processes presumably occur as an indirect consequence of the seasonal decline in gonadotrophin and testosterone secretion (Lincoln, 1981). Abnormal degenerative cells may result from disruption of mitotic or meiotic divisions, and increased numbers of retained cytoplasmic droplets probably reflect maturational deficiencies within the epididymis (Lincoln, 1981).

It has been suggested that mammals undergoing a circannual decline in testicular size to $<25 \%$ of the yearly maximum experience seasonal azoospermia (Lincoln, 1981). Although this generalization accurately applies to red deer, fallow deer and roe deer (Lincoln, 1981), testicular volume in Eld's deer declined during the regressed phase of the testicular cycle to $24.6 \%$ of the seasonal maximum, yet motile spermatozoa were collected throughout the year. A decline to $<25 \%$ of maximal testis size was also reported in chital deer, another species that failed to become azoospermic during the nadir of the testicular cycle (Loudon and Curlewis, 1988). Thus, subtropical cervids appear to differ from temperate species in the degree to which spermatogenesis is arrested during the regressed phase of the seasonal testicular cycle.

Chital (Loudon and Curlewis, 1988) and rusa deer (van Mourik and Stelmasiak, 1985; van Mourik et al., 1986) are the only other 'tropical' species in which circannual testicular cycles have been studied in detail (both were studied at temperate latitudes). There is evidence that most chital deer maintained at $27^{\circ} \mathrm{N}$ (in native Nepal) rut during the spring (March-May) (Mishra and Wemmer, 1987). However, individual chital stags, originating from the Indian subcontinent and maintained at $51^{\circ} \mathrm{N}$, exhibit 13 month testicular-antler cycles that are poorly synchronized among males within the same herd. Antler development, morphometric characteristics and testosterone concentrations parallel changes in testis diameter (Loudon and Curlewis, 1988). However, the absence of synchrony among herd-mates suggests that photoperiod may not be involved in modulating the reproductive axis in this species (Loudon and Curlewis, 1988). In contrast, tropical rusa deer (native to equatorial regions of Java, Timor and the Celebes) maintained in southern Australia $\left(38^{\circ} \mathrm{S}\right)$ exhibit distinct seasonal reproductive patterns: peak fertility occurs during the late winter and spring (July-September) (van Mourik et al., 1986).

An intriguing question remains as to why tropically evolved rusa deer and Eld's deer stags maintained at $38^{\circ} \mathrm{S}$ and $38^{\circ} \mathrm{N}$, respectively, achieve peak reproductive activity during increasing daylengths (winter, spring). Furthermore, why do these species respond 6 months out-of-phase to the same proximate environmental cues experienced by red deer, fallow deer and white-tailed deer living at the same temperate latitudes? The evolution of neuroendocrine responsiveness to hormones such as prolactin and melatonin probably served to reinforce seasonal reproductive rhythms in temperate species. In contrast, tropical cervids are not exposed to strong circannual photoperiodic rhythms, and, therefore, it is possible that selective pressures have favoured the evolution of reproductive patterns designed to exploit fluctuations in local food or habitat resources rather than photoperiod. For example, food abundance in tropical habitats is influenced by annual rainfall patterns. Thus, tropical species translocated to temperate environments may not respond to changing photoperiod, but rather may express endogenous rhythms linked to historical patterns of resource availability in the tropics.

Captive Eld's deer have now been maintained in temperate zones for more than 50 years, and even as far north as $48^{\circ} \mathrm{N}$, they continue to exhibit seasonal reproductive rhythms that are identical to patterns observed in their native subtropical habitat (Prescott, 1987). An alternative explanation to the endogenous rhythm theory is that Eld's deer may be responsive to subtle low amplitude photoperiod oscillations experienced in their native northern subtropical latitudes. Eld's deer may differ from temperate cervids only by responding 6 months out-of-phase to the same photoperiodic cues. Thus, translocating a tropical or subtropical cervid to northern, temperate latitudes may serve to further reinforce or strengthen seasonal rhythms because the 
direction of photoperiod change is similar and the amplitude of seasonal daylength changes is more pronounced.

Despite strong seasonal metabolic and hormonal rhythms, apparent reproductive synchrony among individuals, and the suggestion that prolactin rhythms are tracking photoperiod, further studies are warranted to determine whether Eld's deer, and other tropical cervids, are truly photoresponsive. Detailed studies of tropical cervids in native environments to determine the impact of uniform photoperiod, seasonal rainfall patterns and food availability on reproductive seasonality are also necessary.

This research was funded by an NIH Clinical Investigator Award to S. L. Monfort (HD 00903), grants from the Scholarly Studies Program of the Smithsonian Institution, the Friends of the National Zoo and the Women's Committee of the Smithsonian Associates. We especially thank M. Smak and the many volunteers of the Rivinus Barn for assisting with sample collection and P. Chakraborty and the Uniformed Services University for the Health Sciences, Bethesda, MD, USA for technical support.

\section{References}

Asher GW, Peterson AJ and Bass JJ (1989) Seasonal pattern of LH and testosterone secretion in adult fallow deer, Dama dama Joumal of Reproduction and Fertility 85 657-665

Barrell GK, Muir PD and Sykes AR (1985) Seasonal profiles of plasma testosterone, prolactin, and growth hormone in red deer stags. In Biology of Deer Production. Bulletin 22, pp 185-190. Ed. P Fennessey and K. Drew. The Royal Society of New Zealand. Wright and Carman Ltd, Upper Hutt

Bronson FH (1988) Seasonal regulation of reproduction in marnmals In The Physiology of Reproduction. pp I831-1871 Eds E Knobil and J Neill. Raven Press, New York

Brown JL and Chakraborty PK (1991) Comparison of compensatory pituitary and testicular responses to hemicastration between prepubertal and mature rats Joumal of Andrology 12 119-125

Brown JL, Stuart LD and Chakraborty PK (1987) Endocrine profiles, testicular gonadotropin receptors and sperm production in hemi-castrated ram lambs Journal of Animal Science 65 1563-1570

Brown JL, Wildt DE, Raath JR, de Vos V. Howard JG, Janssen DL, Citino SB and Bush M (1991a) Impact of season on seminal characteristics and endocrine status of adult free-ranging African buffalo (Syncerus caffer) Journal of Reproduction and Fertility $9247-57$

Brown JL, Wildt DE, Raath JR, de Vos V, Janssen DL, Citino SB, Howard JG and Bush M (1991b) Seasonal variation in pituitary-gonadal function in freeranging impala Journal of Reproduction and Fertility 93 497-505

Brown JL, Bush M, Packer C, Pusey AE, Monfort SL, O'Brien SJ, Janssen DL and Wildt DE (1993) Hormonal characteristics of free-ranging female lions (Panthera leo) of the Serengeti Plains and Ngorongoro Crater Joumal of Reproduction and Fertility 97 107-114

Bubenik GA (1990) Neuroendocrine regulation of the antler cycle. In Homs, Pronghorns, and Antlers, pp 267-270 Eds GA Bubenik and AB Bubenik. Springer-Verlag, New York

Bubenik GA, Morris JM, Schams D and Claus A (1982) Photoperiodicity and circannual levels of LH, FSH, and testosterone in normal and castrated male, white-tailed deer Canadian Joumal of Physiology and Pharmacology 60 788-793

Bubenik GA, Schams D and Coenen G (1987) The effect of artificial photoperiodicity and antiandrogen treatment on the antler growth and plasma levels of LH, FSH, testosterone, prolactin and alkaline phosphatase in the male white-tailed deer Comparative Biochemistry and Physiology 87A 551-559

Bubenik GA, Brown RD and Schams D (1990) The effect of latitude on the seasonal pattern of reproductive hormones in the male white-tailed deer Comparative Biochemistry and Physiology $97253-257$

Chaplin RE and White RWG (1972) The influence of age and season on the activity of the testes and epididymides of the fallow deer. Dama dama Journal of Reproduction and Fertility 30 361-369
Chenoweth PJ and Ball L (1980) Breeding soundness evaluation in bulls. In Current Therapy in Theriogenology, pp 330-339 Ed. DA Morrow. W.B. Saunders, Philadelphia

de Jong FH (1988) Inhibin Physiological Reviews 68 555-607

Desai JH and Malhotra AK (1970) The Manipur brow-antlered, (Cervus eldi eldi): Its status and breeding in captivity International Zoo Yearbook 18 235-236

Fraser AF (1968) Reproductive Behaviour in Ungulates Academic Press, New York

Haigh JC, Cates WF, Glover GJ and Rawlings NC (1984) Relationships between seasonal changes in serum testosterone concentrations, scrotal circumference and sperm morphology of male wapiti (Cerous elaphus) Joumal of Reproduction and Fertility 70 $413-418$.

Howard JG, Bush M and Wildt DE (1986) Semen collection, analysis and cryopreservation in nondomestic mammals. In Current Therapy in Theriogenology, pp 1047-1053 Ed. DA Morrow. W.B. Saunders, Philadelphia

Kelly RW, McNatty KP, Moors GM, Ross D and Gibb M (1982) Plasma concentrations of $\mathrm{LH}$, prolactin, oestradiol and progesterone in female red deer (Cerous elaphus) during pregnancy Journal of Reproduction and Fertility 64 475-483

Lincoln GA (1971) The seasonal reproductive changes in the red deer stag (Cerous elaphus) Journal of the Zoology, London 163 105-123

Lincoln GA (1981) Seasonal aspects of testicular function. In Comprehensive Endocrinology: The Testis, pp 255-302 Eds H Burger and D de Kretser. Raven Press, New York

Lincoln GA (1985) Seasonal breeding in deer. In Biology of Deer Production. Bulletin 22, pp 165-179. Ed. P Fennessey and K Drew. The Royal Society of New Zealand. Wright and Carman Ltd, Upper Hutt

Lincoln GA (1990) Correlation with changes in horns and pelage, but not reproduction, of seasonal cycles in the secretion of prolactin in rams of wild, feral and domesticated breeds of sheep Journal of Reproduction and Ferfility 90 285-296

Lincoln GA and Davidson W (1977) The relationship between sexual and aggressive behaviour, and pituitary and testicular activity during the seasonal sexual cycle of rams, and the influence of photoperiod Journal of Reproduction and Fertility $49267-276$

Lincoln GA and Guinness $F$ (1973) The sexual significance of the rut in red deer Joumal of Reproduction and Fertility Supplement 19 475-489

Lincoln GA and Kay RNB (1979) Effects of season on the secretion of LH and testosterone in intact and castrated red deer stags (Cerous elaphus) Journal of Reproduction and Fertility 55 75-80

Lincoln GA and McNeilly AS (1989) Inhibin concentrations in the peripheral blood of rams during a cycle in testicular activity induced by changes in photoperiod or treatment with melatonin Journal of Endocrinology 120 R9-R13

Lincoln GA and Short RV (1980) Seasonal breeding: nature's contraceptive Recent Progress in Hormone Research 36 I-52

Lincoln GA, Lincoln CE and McNeilly AS (1990) Seasonal cycles in the blood plasma concentration of $\mathrm{FSH}$, inhibin and testosterone, and testicular size in rams of wild, feral and domesticated breeds of sheep Journal of Reproduction and Fertility $\mathbf{8 8} 623-633$

Loudon ASI (1991) Nutritional physiology of some Asian ruminants. In Physiological Aspects of Digestion and Metabolism in Ruminants: Proceedings of the Seventh International Symposium on Ruminant Physiology, pp 403-425 Ed. T Tsuda. Academic Press Inc., New York

Loudon ASI and Brinklow BR (1992) Reproduction in deer: adaptations for life in seasonal environments. In Second International Symposium on the Biology of Deer, pp 261-278 Ed. RD Brown. Springer-Verlag, New York

Loudon ASI and Curlewis JD (1988) Cycles of antler and testicular growth in an aseasonal tropical deer (Axis axis) journal of Reproduction and Fertility $\mathbf{8 3}$ 729-738

Loudon ASI, Milne JA, Curlewis JD and McNeilly AS (1989) A comparison of the seasonal hormone changes and patterns of growth, voluntary food intake and reproduction in juvenile and adult red (Cervus elaphus) and Père David's deer (Elaphurus davidianus) hinds Journal of Endocrinology 122 733-745

McDowell EM (1978) Fixation and processing. In Diagnostic Electron Microscopy, pp 113-139 Eds BF Trump and RT Jones. Wiley and Sons, New York

McMillin MJ, Seal US, Keenlyne KD, Erickson AW and Jones JE (1974) Annual testosterone rhythm in the adult white-tailed deer (Odocoileus virginianus borealis) Endocrinology 94 1034-1040

Meschaks P and Nordkvist $M$ (1962) On the sexual cycle in the reindeer male Acta Veterinaria Scandanavia 3 151-162

Mirarchi RE, Howland BE, Scanlon PF, Kirkpatrick RL and Sanford LM (1978) Seasonal variation in plasma $\mathrm{LH}, \mathrm{FSH}$, prolactin, and testosterone concentrations in adult male white-tailed deer Canadian Journal of Zoology 56 121-127 
Mishra HR and Wemmer C (1987) The comparative breeding ecology of four cervids in Royal Chitwan National Park. In Biology and Management of the Cervidae, pp 259-271 Ed. CM Wemmer. Smithsonian Institution Press, Washington, D.C.

Monfort SL, Wemmer C, Kepler TH, Bush M, Brown JL and Wildt DE (1990) Monitoring ovarian function and pregnancy in Eld's deer (Cervus eldi thamin) by evaluating urinary steroid metabolite excretion Journal of Reproduction and Fertility 88 271-281

Mossing T and Damber J (1981) Rutting behavior and androgen variation in reindeer (Rangifer tarandus L.) Journal of Chemical Ecology 7 377-389

Prescott J (1987) The status of the Thailand brow-antlered deer (Cervus eldi siamensis) in captivity Mammalia 51 571-577

Ryg $\mathbf{M}$ and Jacobson $\mathbf{E}$ (1982) Effects of thyroid hormones and prolactin on food intake and weight change in young male reindeer (Rangifer tarandus) Canadian Journal of Zoology $601562-1567$

Salter RE and Sayer JA (1986) The brow-antlered deer in Burma - its distribution and status Oryx $20241-245$

Sanford LM, Howland BE and Palmer WM (1984) Seasonal changes in the endocrine responsiveness of the pituitary and testes of male sheep in relation to their patterns of gonadotrophin hormone and testosterone secretion Canadian Joumal of Physiology and Pharmacology 62 827-833

Schams D and Barth D (1982) Annual profiles of reproductive hormones in peripheral plasma of the male roe deer (Capreolus capreolus) Journal of Reproduction and Fertility 66 463-468

Schams D, Barth D and Karg H (1987) Is antler growth in adult roe deer (Capreolus capreolus) influenced by treatment in estradiol-17 $\beta$, an antiandrogen, or prolactin inhibitor? In Endocrine Regulations as Adaptive Mechanisms to the Environment, pp 475-482 Eds I Assenmacher and J Boissin. CNRS-CEBAS France

Sempéré AJ and Lacroix A (1982) Temporal and seasonal relationships between $\mathrm{LH}$, testosterone and antlers in fawn and adult male roe deer (Capreolus capreolus L.): a longitudinal study from birth to four years of age Acta Endocrinologica 99 295-301
Short RV and Mann T (1966) Tally breeding mammal, the roebuck, Capreolus capreolus Journal of Reproduction and Fertility 12 337-351

Shulte BA, Seal US, Plotka ED, Letellier MA, Verme LJ, Ozoga JJ and Parsons JA (1981) The effect of pinealectomy on seasonal changes in prolactin secretion in the white-tailed deer (Odocoileus virginianus borealis) Endocrinology 108 173-178

Stokkan KA, Hove K and Carr WR (1980) Plasma concentrations of testosterone and luteinizing hormone in rutting reindeer bulls (Rangifer tarandus) Canadian Journal of Zoology 58 2081-2083

Suttie JM, Lincoln GA and Kay RNB (1984) Endocrine control of antler growth in red deer stags Joumal of Reproduction and Fertility 71 7-15

van Mourik S and Stelmasiak T (1985) Seasonal variation in plasma prolactin concentrations in adult, male rusa deer (Cervus rusa timorensis) Comparative Biochemistry and Physiology 82 323-327

van Mourik S, Stelmasiak T and Outch KH (1986) Seasonal variation in plasma testosterone, luteinizing hormone concentrations and $\mathrm{LH}-\mathrm{RH}$ responsiveness in mature, male Rusa deer (Cervus rusa timorensis) Comparative Biochemistry and Physiology 83 347-351

Wemmer C and Grodinsky C (1988) Reproduction in captive female browantlered deer (Cervus eldi thamin) Journal of Mammalogy 75 389-393

West NO and Nordan HC (1976) Hormonal regulation of reproduction and the antler cycle in male Columbian black-tailed deer (Odocoileus hemionus columbianus). Part I. Seasonal changes in the histology of the reproductive organs, serum testosterone, sperm production, and the antler cycle Canadian Journal of Zoology 54 1617-1636

Whitehead PE and McEwan EH (1973) Seasonal variation in the plasma testosterone concentrations of reindeer and caribou Canadian Journal of Zoology 51 , $651-658$

Wislocki GB (1943) Seasonal changes in the testes, epididymides and seminal vesicles of deer investigated by histochemical methods Endocrinology 44 167-189

Wildt DE, Baas EJ, Chakraborty PK, Wolfle TL and Stewart AP (1982) Influence of inbreeding on reproductive performance, ejaculate quality and testicular volume in the dog Theriogenology 17 445-452 